\title{
Production and transformation of dissolved neutral sugars and amino acids by bacteria in seawater
}

\author{
L. Jørgensen ${ }^{1,2}$, O. J. Lechtenfeld ${ }^{3}$, R. Benner ${ }^{3}$, M. Middelboe $^{1}$, and C. A. Stedmon ${ }^{2}$ \\ ${ }^{1}$ Marine Biological Section, University of Copenhagen, Strandpromenaden 5, 3000 Helsingør, Denmark \\ ${ }^{2}$ National Institute for Aquatic Resources, Technical University of Denmark, Kavalergården 6, 2920 Charlottenlund, Denmark \\ ${ }^{3}$ Marine Science Program, University of South Carolina, Columbia, South Carolina 29208, USA \\ Correspondence to: L. Jørgensen (linda.jor.85@gmail.com)
}

Received: 7 April 2014 - Published in Biogeosciences Discuss.: 29 April 2014

Revised: 12 August 2014 - Accepted: 24 August 2014 - Published: 7 October 2014

\begin{abstract}
Dissolved organic matter (DOM) in the ocean consists of a heterogeneous mixture of molecules, most of which are of unknown origin. Neutral sugars and amino acids are among the few recognizable biomolecules in DOM, and the molecular composition of these biomolecules is shaped primarily by biological production and degradation processes. This study provides insight into the bioavailability of biomolecules as well as the chemical composition of DOM produced by bacteria. The molecular compositions of combined neutral sugars and amino acids were investigated in DOM produced by bacteria and in DOM remaining after 32 days of bacterial degradation. Results from bioassay incubations with natural seawater (sampled from water masses originating from the surface waters of the Arctic Ocean and the North Atlantic Ocean) and artificial seawater indicate that the molecular compositions following bacterial degradation are not strongly influenced by the initial substrate or bacterial community. The molecular composition of neutral sugars released by bacteria was characterized by a high glucose content $(47 \mathrm{~mol} \%)$ and heterogeneous contributions from other neutral sugars (3-14 mol\%). DOM remaining after bacterial degradation was characterized by a high galactose content $(33 \mathrm{~mol} \%)$, followed by glucose $(22 \mathrm{~mol} \%)$ and the remaining neutral sugars $(7-11 \mathrm{~mol} \%)$. The ratio of D-amino acids to L-amino acids increased during the experiments as a response to bacterial degradation, and after 32 days, the $\mathrm{D} / \mathrm{L}$ ratios of aspartic acid, glutamic acid, serine and alanine reached around $0.79,0.32,0.30$ and 0.51 in all treatments, respectively. The striking similarity in neutral sugar and amino acid compositions between natural (representing marine semi-labile and refractory DOM) and artificial (rep-
\end{abstract}

resenting bacterially produced DOM) seawater samples, suggests that microbes transform bioavailable neutral sugars and amino acids into a common, more persistent form.

\section{Introduction}

Approximately 700 petagrams $\left(10^{15} \mathrm{~g}\right)$ of carbon in the ocean are in the form of dissolved organic matter (DOM) and consist of a broad range of different chemical compounds spanning a continuum of sizes and reactivities (Hansell, 2013; Siegenthaler and Sarimento, 1993). Although all organic matter originates from organisms, only about $6.6 \%$ of surface DOM and 2\% of deep ocean DOM is identified as specific biomolecules such as neutral sugars and amino acids (Benner, 2002). Despite their low concentrations, the rapid turnover of simple biomolecules suggests that they play an important role in the cycling of carbon and nitrogen in the ocean (Rich et al., 1997, 1996; Skoog et al., 1999). However, several studies have also indicated that some biomolecules can resist bacterial degradation over year-long timescales (Kirchman et al., 2001; Ogawa et al., 2001). Heterotrophic bacteria are well known sources of semi-labile and refractory DOM (Kaiser and Benner, 2008; McCarthy et al., 1998; Ogawa et al., 2001), and $23 \%$ of the entire DOC pool is estimated to derive from bacteria via the microbial carbon pump (microbial transformation of bioavailable DOM to refractory DOM) (Benner and Herndl, 2011; Jiao et al., 2010). However, still only little is known about microbial production of specific semi-labile and refractory biomolecules. This is in part due to the low concentration of individual 
biomolecules in seawater and the consequent analytical challenge involved.

The most common biomolecules in the oceanic DOM pool are carbohydrates (Benner et al., 1992), with neutral sugars constituting up to half of the total carbohydrate pool (Biersmith and Benner, 1998). Seven different neutral sugars are commonly detected (fucose, rhamnose, arabinose, galactose, glucose, mannose and xylose), and the amount of each neutral sugar relative to the total amount of neutral sugars (the molecular composition, mol\%) differs between DOM released by different groups of organisms (Lazareva and Romankevich, 2012). The molecular composition can therefore be used as a tracer of different organisms or processes; e.g., freshly released neutral sugars from different algal species exhibit great variation in mol \%, but generally have high contributions of glucose and galactose, each sometimes reaching values above $50 \mathrm{~mol} \%$ (Amon and Benner, 2003; Biersmith and Benner, 1998; Hama and Yanagi, 2001). Surface ocean DOM is also rich in glucose and galactose, with many studies reporting $\sim 20 \mathrm{~mol} \%$ for each of the two compounds (Goldberg et al., 2009; Kaiser and Benner, 2009; Skoog and Benner, 1997). With depth, glucose and fucose increase in relative abundance, accounting for about 20-40\% and 16-19\% in the deep ocean, respectively (Kaiser and Benner, 2009; McCarthy et al., 1996). The molecular composition of neutral sugars directly released by heterotrophic bacteria during growth in the ocean, however, remains unknown. The molecular composition found in the ocean reflects both the neutral sugars released by different organisms and the neutral sugars persisting in organic matter after long-term bacterial degradation, and the sources and sinks are difficult to distinguish. Knowledge of the composition of neutral sugars produced and transformed by heterotrophic bacteria is key to understanding the origin and fate of these specific DOM components in the ocean.

D-enantiomers of amino acids are useful as bacterial biomarkers, since bacteria are the predominant source of Damino acids in seawater (Kaiser and Benner, 2008). Four different pairs of L- and D-amino acids are important in DOM (aspartic acid, glutamic acid, serine and alanine) and the amount of $\mathrm{D}$ relative to $\mathrm{L}$ (the $\mathrm{D} / \mathrm{L}$ ratio) has been used as an indicator of amino acid bioavailability (Jørgensen et al., 1999). Freshly released DOM from phytoplankton has a low $\mathrm{D} / \mathrm{L}$ ratio, but the ratio increases during bacterial degradation of DOM (Amon et al., 2001) due to direct release of D-amino acids by bacteria during growth (Kawasaki and Benner, 2006); viral lysis of cells and the subsequent release of cell wall D-amino acids (Middelboe and Jørgensen, 2006); and a presumably higher bioavailability of L-amino acids (Amon et al., 2001; Hopkins et al., 1994; Pérez et al., 2003). The presence of grazers such as flagellates can also increase the bacterial uptake of D-amino acids, possibly due to a higher release from bacterivory and subsequent microbial uptake (Pérez et al., 2003). The D/L ratio does not follow a certain pattern with depth in the ocean. Both a decrease, an increase and no change has been observed with depth in different studies (Jørgensen et al., 1999; Kaiser and Benner, 2008; McCarthy et al., 1998; Pérez et al., 2003), making it difficult to distinguish between different sources and sinks and the balance between these. Knowledge of the D/L ratio in freshly produced DOM and in DOM remaining after long-term microbial degradation is necessary to understand the origin and fate of amino acids in the ocean.

In the present study, we investigated the concentration, composition and bioavailability of neutral sugars and amino acids in two seawater samples collected between Greenland and Iceland, representing cold seawater originating from the Arctic Ocean and warm seawater originating from the Atlantic Ocean, respectively. During 32-day bioassay incubations of seawater samples and parallel glucose-enriched artificial seawater samples, the bacterial production and decomposition of individual neutral sugars and amino acids were investigated. The aim was to compare the molecular composition of biomolecules in DOM produced by bacteria and in DOM remaining after long-term bacterial degradation, and to use these molecular signatures of bacterial activity to further understand the origin of neutral sugars and amino acids in the ocean.

\section{Methods}

\subsection{Sampling site and incubation experiments}

Seawater for the 32-day incubations was collected from two different locations in the Denmark Strait: at $10 \mathrm{~m}$ depth in the warm $\left(9.8^{\circ} \mathrm{C}\right)$ northwards traveling North Icelandic Irminger Current (henceforth referred to as the Atlantic sample) and at $80 \mathrm{~m}$ depth in the cold $\left(-1.6^{\circ} \mathrm{C}\right)$ southwards traveling East Greenland Current (henceforth referred to as the Arctic sample, Fig. 1). The Arctic Ocean receives a large amount of freshwater, supplying $25-36 \mathrm{Tg}\left(10^{12} \mathrm{~g}\right)$ in terrigenous dissolved organic carbon (DOC) per year (Raymond et al., 2007), and up to $41 \%$ of this DOC is exported through the Fram Strait (Opsahl et al., 1999). The East Greenland Current transports cold Arctic water from the Fram Strait south along the Greenland shelf, where it mixes with water from the North Atlantic Ocean (Stein, 1988). The seawater collected for bioassay incubations included terrigenous DOM from the Arctic Ocean as well as marine DOM from the Atlantic Ocean.

Six different treatments, all consisting of $90 \% 0.2 \mu \mathrm{m}$ filtered seawater and $10 \% \mathrm{GF} / \mathrm{C}$ filtered inoculum, were incubated for 32 days in the dark at $18^{\circ} \mathrm{C}$. Three treatments of Arctic and three treatments of Atlantic samples were incubated: a natural seawater sample (NSW), an artificial seawater sample with $60 \mu \mathrm{M}$ glucose $\mathrm{C}$ as the only carbon source $\left(\mathrm{ASW}_{\mathrm{glu}}\right)$ and a natural seawater sample spiked with $60 \mu \mathrm{M}$ glucose $\mathrm{C}\left(\mathrm{NSW}_{\mathrm{glu}}\right)$. Hence, the carbon pool consisted of either natural DOM, glucose or both. Only two different 


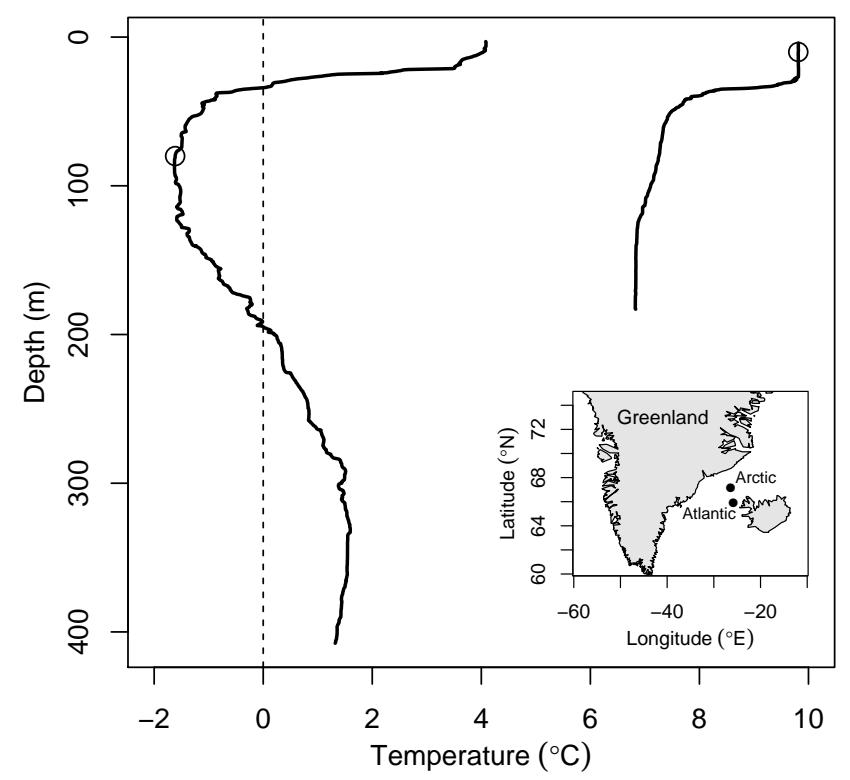

Figure 1. Temperature profiles at the Atlantic and Arctic sampling sites. Seawater for 32-day incubations was collected at 10 and $80 \mathrm{~m}$ depth at the Atlantic and Arctic stations, respectively (indicated by circles).

bacterial inoculums were used: one from the Arctic and one from the Atlantic sampling site. All samples were amended with inorganic $\mathrm{N}$ and $\mathrm{P}$ to have $10 \mu \mathrm{M} \mathrm{KNO}_{3}$ and $2 \mu \mathrm{M}$ $\mathrm{Na}_{2} \mathrm{HPO}_{4}$ at the beginning of the incubations. $\mathrm{N}$ and $\mathrm{P}$ were added in excess to reduce the risk of nutrient limitation during the incubations.

Onboard the ship, the majority of the seawater was filtered through a $0.2 \mu \mathrm{m}$ cartridge filter (Millipore Opticap) to obtain the DOM fraction, and a small bacterial inoculum was filtered through a GF/C filter (Whatman, $\sim 1.2 \mu \mathrm{m}$ ). Both filters were cleaned with ample amounts of seawater before the filtrates were collected. The filtrates were acclimated to $18^{\circ} \mathrm{C}$ in the dark for approximately $24 \mathrm{~h}$, and the incubations were initiated by the addition of bacterial inoculum to the $0.2 \mu \mathrm{m}$ filtered water in acid-washed amber glass bottles. Each of the six treatments consisted of nine amber glass bottles $(200 \mathrm{~mL})$ of seawater, and three bottles were sacrificed during each subsampling. The artificial seawater for $\mathrm{ASW}_{\text {glu }}$ samples was prepared as described by Kester et al. (1967), and adjusted to the salinities of the NSW samples (35.1 and 33.5 for Atlantic and Arctic seawater, respectively) by further addition of MilliQ water. Subsamples for bacterial abundance (all heterotrophic prokaryotes), DOC concentration, dissolved combined neutral sugars and amino acids were taken on days 0,6 and 32. Bacterial abundance and DOC were measured from all triplicate bottles, while neutral sugars and amino acids were measured from a single bottle. All samples from day 0 were taken approximately $12 \mathrm{~h}$ after the addition of inoculum, glucose and nutrients.

\subsection{Sample analysis}

Subsamples for determination of bacterial abundance were fixed with glutaraldehyde (1.3\% final concentration) and stored frozen $\left(-80^{\circ} \mathrm{C}\right)$ until measurement. Bacteria were counted by flow cytometry on a BD FACS Canto II flow cytometer using the nucleic acid stain SYBR Green to stain the fixed cells (Marie et al., 1997). Subsamples for measurement of DOC concentration were $0.2 \mu \mathrm{m}$ filtered (Acrodisc) and collected in acid-cleaned high-density polyethylene (HDPE) bottles. The samples were acidified with $2 \mathrm{MHCl}$ to a $\mathrm{pH}$ of 2 and stored cold $\left(5^{\circ} \mathrm{C}\right)$ until analysis on a Shimadzu TOC- $\mathrm{V}_{\mathrm{CPH}}$ analyzer. The instrument was calibrated using a standard series made from acetoanilide, and performance was evaluated using deep-sea water reference material made available by the Hansell CRM program. The measured concentration of DOC in the deep-sea reference $(41-43 \mu \mathrm{M})$ corresponded well to values from the Hansell CRM program $(41-44 \mu \mathrm{M})$.

Neutral sugars and amino acids were measured from $0.2 \mu \mathrm{m}$ filtered subsamples collected in acid-cleaned HDPE bottles that were stored frozen $\left(-20^{\circ} \mathrm{C}\right)$ until analysis. The concentration of free and combined hydrolyzable neutral sugars (fucose, rhamnose, arabinose, galactose, glucose, mannose and xylose) was measured on a Dionex 500 ion chromatography system with pulsed amperometric detection (PAD) as described by Skoog and Benner (1997) and Kaiser and Benner (2009). The relative deviation from the mean of replicate hydrolysis (excluding replicate experiments) was $29-40 \%$ for concentrations less than $20 \mathrm{nM}$, and $10-33 \%$ for concentrations greater than $20 \mathrm{nM}$ of individual neutral sugars. For total hydrolyzable neutral sugars the relative deviation from the mean was $15 \%$. Free and combined hydrolyzable amino acids were analyzed according to Kaiser and Benner (2005) on an Agilent 1260 UPLC using a fluorescence detector and corrected for hydrolysis induced racemization (Kaiser and Benner 2005). The concentration of the following amino acids was measured: L- and D-asparagine (asparagine and aspartic acid), L- and D-glutamine (glutamine and glutamic acid), L- and D-serine, L-histidine, Lthreonine, glycine, L-arginine, $\beta$-alanine, $\mathrm{L}$ - and $\mathrm{D}$-alanine, $\gamma$-aminobutyric acid, L-tyrosine, L-valine, L-methionine, Lphenylalanine, L-isoleucine, L-leucine and L-lysine. The relative deviation from the mean of duplicate hydrolysis (excluding replicate experiments) was $4-23 \%$ for concentrations less than $10 \mathrm{nM}$, and 3-8\% for concentrations greater than $10 \mathrm{nM}$ of individual amino acids. For total hydrolyzable amino acids, the relative deviation from the mean was $8 \%$. 

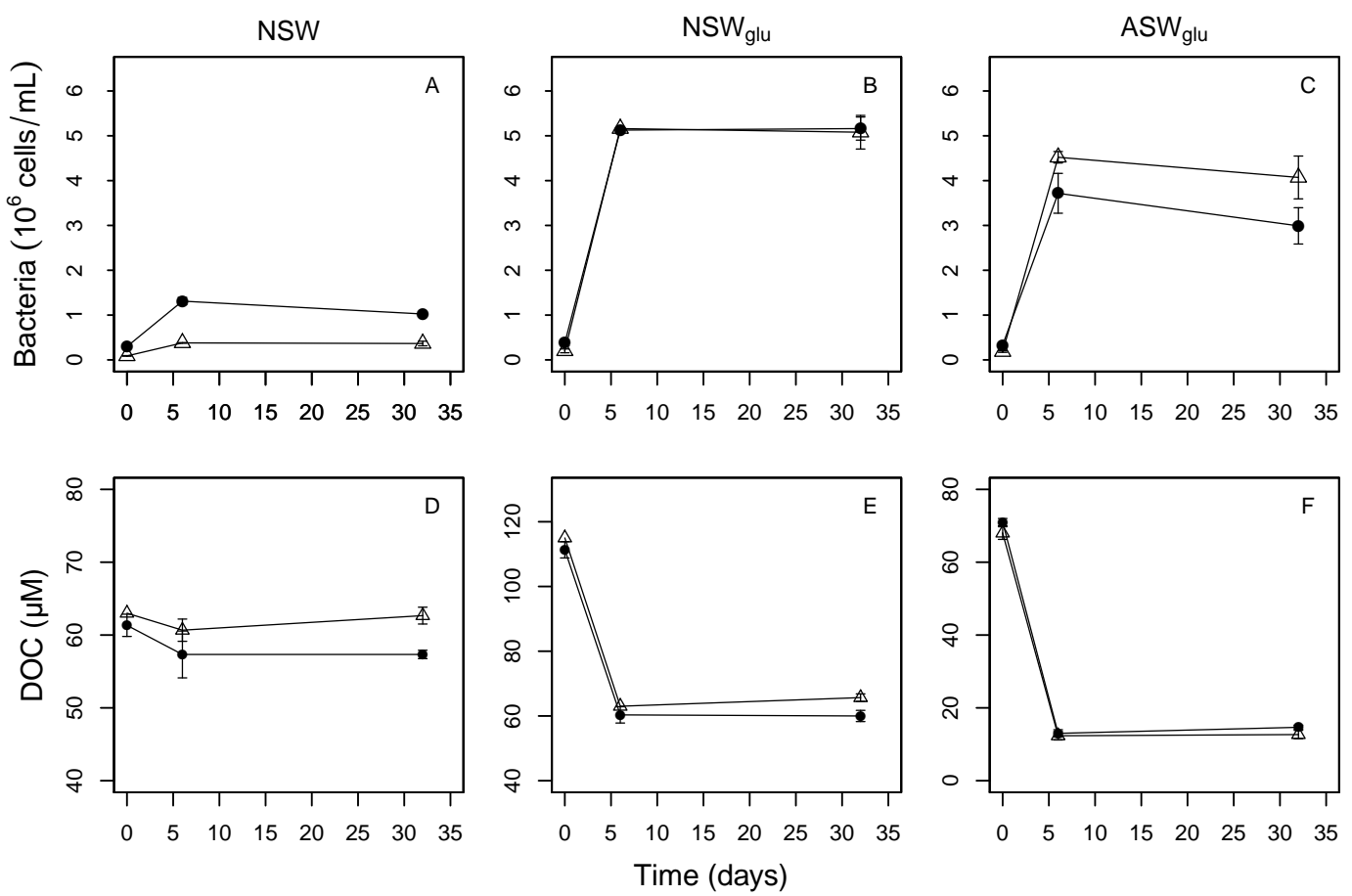

Figure 2. Bacterial abundance and DOC concentration. The data points and error bars represent means and standard deviations calculated from triplicate measurements. $\bullet$ represents Atlantic treatments and $\Delta$ represents Arctic treatments. Note the different scales of the axes.

\subsection{Terminology and calculations}

The sum of all neutral sugars and the sum of all amino acids measured are termed total hydrolyzable neutral sugars (THNS) and total hydrolyzable amino acids (THAA), respectively. The contributions of THNS and THAA to total DOM (the yields) were calculated as the ratio of carbon bound in either THNS or THAA to the total concentration of DOC. For THAA, the calculations excluded the non-protein amino acids $\beta$-alanine and $\gamma$-aminobutyric acid. The mol\% of a specific compound was calculated as the molar ratio of the compound concentration to the total concentration of compounds, THNS or THAA.

To investigate the neutral sugars produced by bacteria after utilization of the added glucose, the concentration and composition of neutral sugars on day 6 in glucose-enriched treatments were compared to the corresponding values of the NSW samples. For the $\mathrm{NSW}_{\text {glu }}$ samples, it was necessary to take into account that a fraction of neutral sugars was bound in natural oceanic DOM. Assuming that bacterial transformation of natural oceanic DOM was similar in the NSW and $\mathrm{NSW}_{\text {glu }}$ samples, a subtraction of the concentration of individual neutral sugars (NS) in the NSW samples from the corresponding concentrations in the $\mathrm{NSW}_{\text {glu }}$ samples allowed an estimation of neutral sugars produced by bacteria in the $\mathrm{NSW}_{\text {glu }}$ samples:

$\mathrm{NS}_{\text {bacterially produced }}=\mathrm{NS}_{\mathrm{NSW}_{\mathrm{glu}}}-\mathrm{NS}_{\mathrm{NSW}}$.
For $\mathrm{ASW}_{\text {glu }}$ samples, only the neutral sugars bound in the $10 \%$ inoculum had to be subtracted, assuming similar concentrations and compositions in the inoculum and the NSW samples:

$\mathrm{NS}_{\text {bacterially produced }}=\mathrm{NS}_{\mathrm{ASW}_{\text {glu }}}-0.1 \times \mathrm{NS}_{\mathrm{NSW}}$.

\section{Results}

\subsection{Bacterial abundance and dissolved organic carbon}

The abundance of bacteria was low at the beginning of the experiments, with fewer than $0.4 \times 10^{6}$ cells $\mathrm{mL}^{-1}$ in Atlantic samples and fewer than $0.2 \times 10^{6}$ cells mL ${ }^{-1}$ in Arctic samples (Fig. 2a, b and c). During the first 6 days of the experiment, the abundance increased considerably in all treatments, reaching $1.3 \times 10^{6}$ and $0.4 \times 10^{6}$ cells $\mathrm{mL}^{-1}$ in Atlantic and Arctic NSW samples and between $3.7 \times 10^{6}$ and $5.2 \times 10^{6}$ cells $\mathrm{mL}^{-1}$ in glucose-enriched treatments. From day 6 to day 32, the bacterial abundance stayed constant or decreased slightly in all samples. The initial DOC concentrations in Atlantic and Arctic samples were approximately 60, 115 and $70 \mu \mathrm{M}$ in NSW, $\mathrm{NSW}_{\text {glu }}$ and $\mathrm{ASW}_{\text {glu }}$ samples, respectively (Fig. 2d, e and f). DOC concentrations decreased in all treatments during the first 6 days and stayed approximately constant from day 6 to day 32 . The net DOC consumption in the Atlantic samples was $4 \pm 3.6,52 \pm 3.6$ and $58 \pm 1.4 \mu \mathrm{M}$ in $\mathrm{NSW}, \mathrm{NSW}_{\text {glu }}$ and $\mathrm{ASW}_{\text {glu }}$ samples, 
respectively. The corresponding values for the Arctic samples were $2 \pm 1.5,52 \pm 0$ and $56 \pm 2.1 \mu \mathrm{M}$ DOC. The DOC consumption after 32 days corresponded to 7 and $1 \%$ of total DOC in the Atlantic and Arctic NSW samples, respectively.

\subsection{Neutral sugars}

The initial concentrations of THNS ranged from 210 to $339 \mathrm{nM}$ in the NSW samples, and from 7041 to $7850 \mathrm{nM}$ in the glucose-enriched samples (Fig. 3a, b and c). THNS decreased in all treatments over time, particularly during the first 6 days of the incubations. After 32 days, the net consumption of THNS in the Atlantic samples was 130, 7585 and $6992 \mathrm{nM}$ in NSW, $\mathrm{NSW}_{\text {glu }}$, and $\mathrm{ASW}_{\text {glu }}$, respectively. The corresponding values for Arctic samples were 84, 6990 and $6943 \mathrm{nM}$. Initially, THNS constituted 3.5 and $2.4 \%$ of total DOC in the Atlantic and Arctic NSW samples, respectively (Fig. 3d). The yields decreased to 2.5 and $1.7 \%$ on day 6 , and continued to decrease at a slower pace during the remaining of the incubations. In the glucose-enriched treatments, the yields were approximately 40 and $63 \%$ in the $\mathrm{NSW}_{\mathrm{glu}}$ and $\mathrm{ASW}_{\mathrm{glu}}$ samples, respectively, decreasing to $\sim 3$ and $9 \%$ after 6 days (Fig. 3e and f). The molecular composition ( $\mathrm{mol} \%)$ of neutral sugars changed over time, but varied little between treatments (Table 1). Galactose and glucose were the most abundant neutral sugars in all samples, together comprising between 38 and $74 \mathrm{~mol} \%$. The glucose mol \% increased from day 0 to day 6 in all samples (disregarding glucose treatments, day 0 ), followed by a decrease from day 6 to day 32 . The galactose mol $\%$ followed the opposite pattern: decreasing during the first 6 days, followed by an increase from day 6 to day 32. At the end of the experiments, galactose was the most abundant neutral sugar, comprising between 21 and $47 \%$. At the same time, glucose only comprised 12 to $32 \%$.

Due to the high concentration of glucose on day 0 in the glucose-enriched treatments, these samples were diluted 100 times prior to analysis. Consequently, no other neutral sugars were determined on day 0 . The molecular composition of neutral sugars produced by bacteria in the glucose-enriched treatments during the first 6 days was calculated as described in the "Methods" section. It was characterized by a high glucose mol \% (47 \pm 12$)$ and a relatively low mol \% of the remaining neutral sugars, ranging from $3 \pm 2$ to $14 \pm 9$ (Table 1). After 32 days, the molecular composition in all samples was characterized by a high galactose mol \% (33 \pm 11$)$, a lower glucose mol \% (22 \pm 8 ), and an even lower mol \% of the remaining neutral sugars, ranging from $7 \pm 5$ to $11 \pm 3$.

\subsection{Amino acids}

The initial concentrations of THAA ranged from 170 to $244 \mathrm{nM}$ in all treatments (Fig. $4 \mathrm{a}, \mathrm{b}$ and c). During the incubations, the concentration of THAA decreased in the Arctic and Atlantic NSW samples. The glucose-enriched sam- ples showed an increased concentration of THAA on day 6 , followed by a decrease. The only exception was the Arctic $\mathrm{ASW}_{\text {glu }}$ sample, which like the NSW samples showed a decreasing THAA concentration throughout the incubation. The yield of THAA in NSW samples decreased from 1.4 to $1.1 \%$ and from 1 to $0.8 \%$ for the Atlantic and Arctic treatments, respectively (Fig. 4d). The yield in $\mathrm{NSW}_{\text {glu }}$ samples increased from 0.7 and $0.6 \%$ on day 0 to 1.5 and $1.8 \%$ on day 6 , and ended at 1.5 and $0.8 \%$ on day 32 in the Atlantic and Arctic samples, respectively (Fig. 4e). The yield in $\mathrm{ASW}_{\text {glu }}$ samples increased from 1.1 and $1.0 \%$ on day 0 to 7.3 and $2.1 \%$ on day 6 , and decreased to 2.3 and $0.7 \%$ on day 32 in the Atlantic and Arctic samples, respectively (Fig. 4f).

The molecular composition (mol\%) of amino acids varied little from sample to sample, and also did not show any notable changes over time (Table 2). Glycine was the most abundant amino acid, comprising between 26 and $40 \mathrm{~mol} \%$. The four amino acids from which both the L- and the Denantiomers have been measured (asparagine, glutamine, serine and alanine) were the second-most abundant amino acids, comprising between 6 and $18 \mathrm{~mol} \%$. The concentration of D-amino acids only changed slightly, while L-amino acids generally decreased in concentration during the time course of the experiments, leading to an increased $\mathrm{D} / \mathrm{L}$ ratio with time (Table 2).

\section{Discussion}

\subsection{Concentration and bioavailability}

In the NSW samples, the initial DOC concentrations (61$63 \mu \mathrm{M})$ were similar to previous measurements from the region (e.g., Amon et al., 2003; Benner et al., 2005). After 32 days, 7 and $1 \%$ of the DOC were consumed in the Atlantic and Arctic NSW samples, respectively. These values are comparable to estimates by Amon and Benner (2003) who estimated around $10 \%$ of Atlantic and $2 \%$ of Arctic DOC to be labile. The initial concentrations of THNS in NSW samples $(210$ and $339 \mathrm{nM})$ were within the range of concentrations $(60-409 \mathrm{nM})$ found in ultrafiltered surface samples $(<0.1 \mu \mathrm{m},<100 \mathrm{~m})$ from the region (Amon and Benner, 2003), and GF/F filtered surface samples from the Sargasso Sea which ranged from $\sim 180$ to $450 \mathrm{nM}$ (Goldberg et al., 2009). A considerable fraction of the neutral sugars in the NSW samples were labile, as indicated by the preferential removal of neutral sugars (Fig. 3d). This trend has also been observed in previous studies (Amon and Benner, 2003; Amon et al., 2001). The initial concentrations of THAA in NSW samples (189 and $244 \mathrm{nM}$ ) corresponded well with values from surface waters of the Sargasso Sea ( 150-200 nM, Lee and Bada 1977; Kaiser and Benner 2008, 2009) and the Arctic Ocean ( 150-500 nM, Dittmar et al., 2001; Shen et al., 2012). The preferential removal of amino acids in NSW 

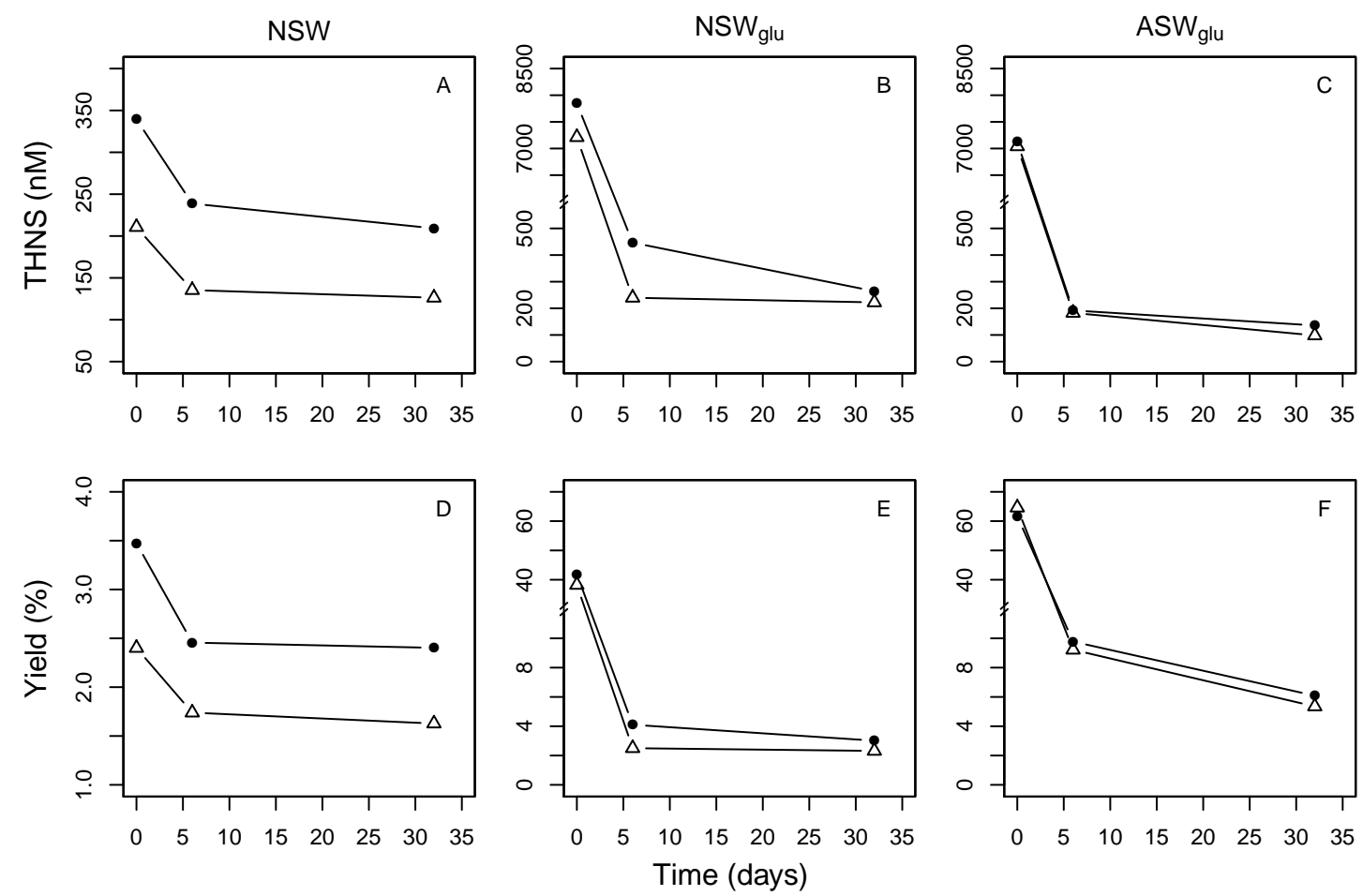

Figure 3. Concentration and yield of total hydrolyzable neutral sugars (THNS). $\bullet$ represents Atlantic treatments and $\Delta$ represents Arctic treatments. Note the different scales of the axes and the broken axes on the plots of the glucose-enriched treatments.
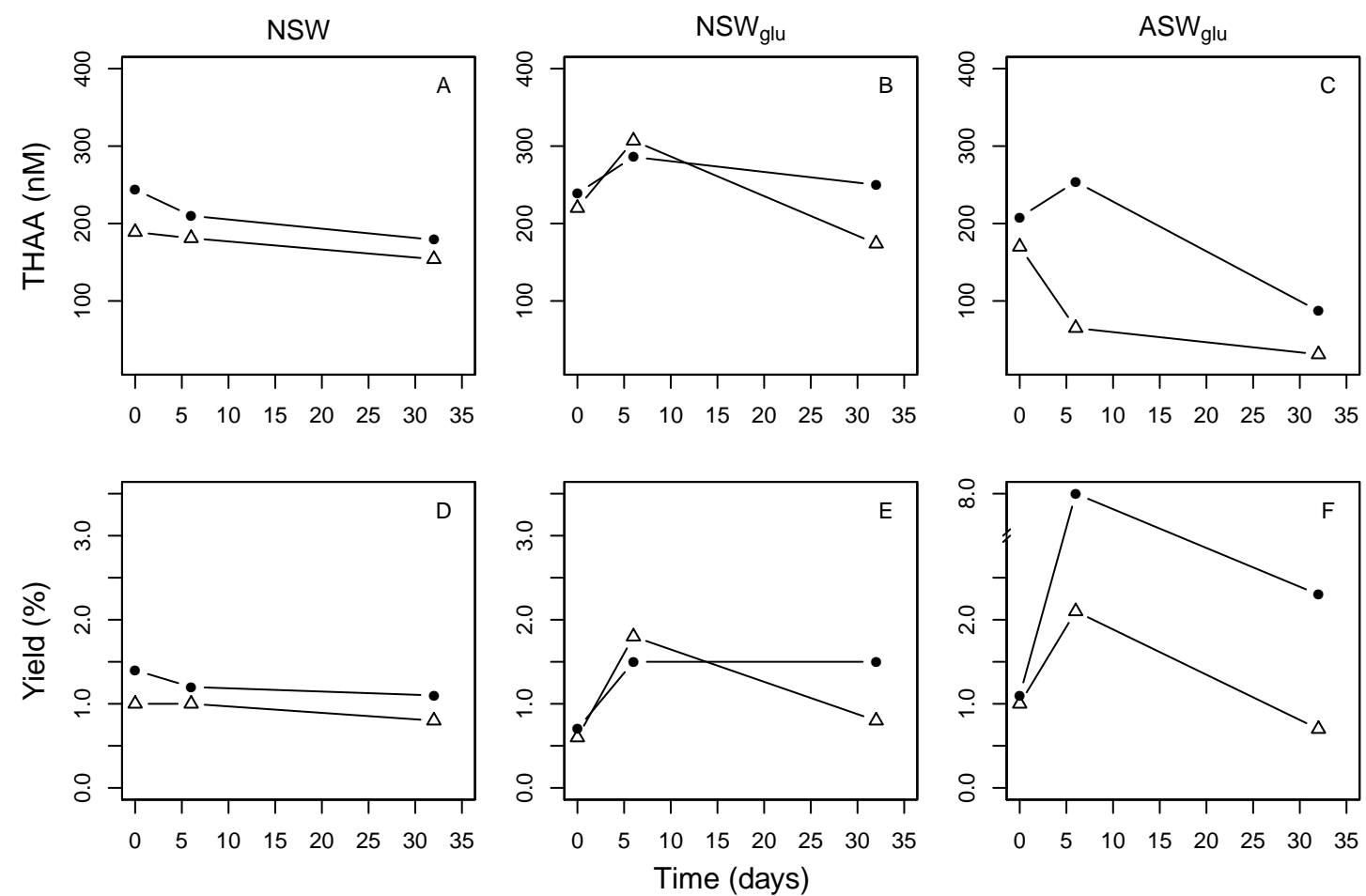

Figure 4. Concentration and yield of total hydrolyzable amino acids (THAA). • represents Atlantic treatments and $\Delta$ represents Arctic treatments. Note the different scales of the axes and the broken axis on the yield plot of the artificial treatments. 
Table 1. Molecular composition of neutral sugars in the six different treatments during the incubations. The neutral sugars produced by bacteria in the glucose-enriched samples during the first 6 days $(n=4$; see "Methods" for an explanation of the calculations) and the neutral sugars remaining after 32 days $(n=6)$ are given as means and standard deviations. nd: not determined.

\begin{tabular}{|c|c|c|c|c|c|c|c|c|}
\hline Day & $\begin{array}{l}\text { THNS } \\
(\mathrm{nM})\end{array}$ & $\begin{array}{l}\text { Fuc } \\
(\mathrm{mol} \%)\end{array}$ & $\begin{array}{l}\text { Rha } \\
(\operatorname{mol} \%)\end{array}$ & $\begin{array}{l}\text { Ara } \\
(\operatorname{mol} \%)\end{array}$ & $\begin{array}{l}\text { Gal } \\
(\mathrm{mol} \%)\end{array}$ & $\begin{array}{l}\text { Glc } \\
(\operatorname{mol} \%)\end{array}$ & $\begin{array}{l}\text { Man } \\
(\operatorname{mol} \%)\end{array}$ & $\begin{array}{l}\text { Xyl } \\
(\mathrm{mol} \%)\end{array}$ \\
\hline \multicolumn{9}{|c|}{ NSW, Atlantic } \\
\hline 0 & 339 & 11 & 10 & 13 & 23 & 17 & 14 & 11 \\
\hline 6 & 239 & 14 & 14 & 9 & 20 & 20 & 13 & 9 \\
\hline 32 & 209 & 12 & 12 & 9 & 27 & 15 & 12 & 12 \\
\hline \multicolumn{9}{|c|}{ NSW, Arctic } \\
\hline 0 & 211 & 7 & 9 & 17 & 16 & 22 & 13 & 16 \\
\hline 6 & 135 & 12 & 13 & 15 & 11 & 29 & 11 & 10 \\
\hline 32 & 126 & 11 & 14 & 12 & 21 & 20 & 10 & 13 \\
\hline \multicolumn{9}{|c|}{$N S W_{\text {glu }}$, Atlantic } \\
\hline 0 & 7850 & nd & nd & nd & nd & 100 & nd & nd \\
\hline 6 & 447 & 10 & 9 & 8 & 18 & 24 & 13 & 17 \\
\hline 32 & 264 & 12 & 10 & 14 & 32 & 12 & 10 & 9 \\
\hline \multicolumn{9}{|c|}{$N S W_{\text {glu }}$, Arctic } \\
\hline 0 & 7212 & nd & nd & nd & nd & 100 & nd & nd \\
\hline 6 & 240 & 7 & 12 & 7 & 15 & 42 & 9 & 9 \\
\hline 32 & 220 & 9 & 12 & 6 & 25 & 32 & 9 & 8 \\
\hline \multicolumn{9}{|c|}{$A S W_{\mathrm{glu}}$, Atlantic } \\
\hline 0 & 7127 & nd & nd & nd & nd & 100 & nd & nd \\
\hline 6 & 192 & 6 & 7 & 14 & 7 & 47 & 7 & 11 \\
\hline 32 & 136 & 4 & 7 & 8 & 46 & 28 & 5 & 2 \\
\hline \multicolumn{9}{|c|}{$A S W_{\mathrm{glu}}, A r c t i c$} \\
\hline 0 & 7041 & nd & nd & nd & nd & 100 & nd & nd \\
\hline 6 & 183 & 4 & 12 & 8 & 13 & 48 & 6 & 9 \\
\hline 32 & 98 & 0 & 14 & 13 & 47 & 25 & 0 & 0 \\
\hline \multicolumn{9}{|c|}{ Bacterially produced neutral sugars } \\
\hline & & $3 \pm 2$ & $8 \pm 4$ & $7 \pm 8$ & $14 \pm 7$ & $47 \pm 12$ & $8 \pm 3$ & $14 \pm 9$ \\
\hline \multicolumn{9}{|c|}{ Composition after 32 days } \\
\hline & & $8 \pm 5$ & $11 \pm 3$ & $10 \pm 3$ & $33 \pm 11$ & $22 \pm 8$ & $8 \pm 5$ & $7 \pm 5$ \\
\hline
\end{tabular}

samples indicated that a fraction of amino acids was labile (Fig. 4d). Our study supports the general notion that neutral sugar and amino acid yields can be used as biochemical indicators of DOC bioavailability (Amon et al., 2001), since the highest DOC consumption was observed in the Atlantic NSW sample, which was also associated with the highest yields of THNS and THAA.

In the glucose-enriched samples, 49-56 $\mu \mathrm{M}$ DOC was consumed during the experiment. The DOC samples on day 0 were collected $12 \mathrm{~h}$ after the addition of glucose, and the actual DOC consumption was therefore likely up to $12-17 \mu \mathrm{M}$ higher (estimated from the missing free glucose). Taking this into account, the DOC consumptions agreed well with the amount of added glucose and, possibly, a small contribution from the original DOM pool. The DOC consumption estimates were calculated from the missing free glucose: glucose was added to a final concentration of $10000 \mathrm{nM}$ before addition of the inoculum. However, the concentrations measured at the beginning of the experiment ranged from 7041 to $7850 \mathrm{nM}$. Sample hydrolysis possibly also altered some of the added glucose, resulting in lower measured concentrations (Skoog and Benner, 1997). The DOC consumption in the $\mathrm{NSW}_{\text {glu }}$ samples $(52 \mu \mathrm{M})$ was lower than in the $\mathrm{ASW}_{\text {glu }}$ samples $(56-58 \mu \mathrm{M})$, despite a higher DOC concentration and an equal amount of glucose. Although this discrepancy is small, it may represent a minor contribution of 


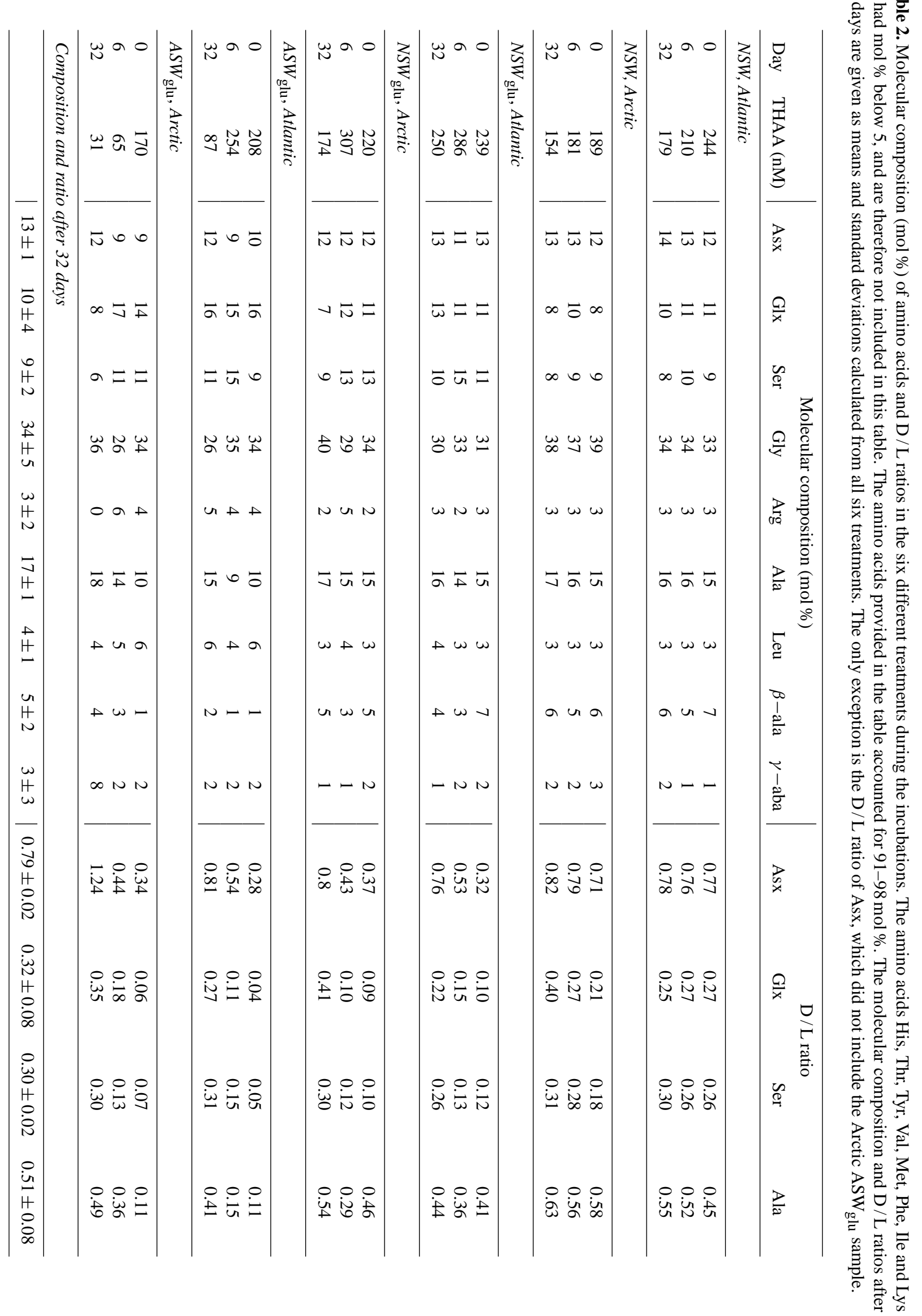




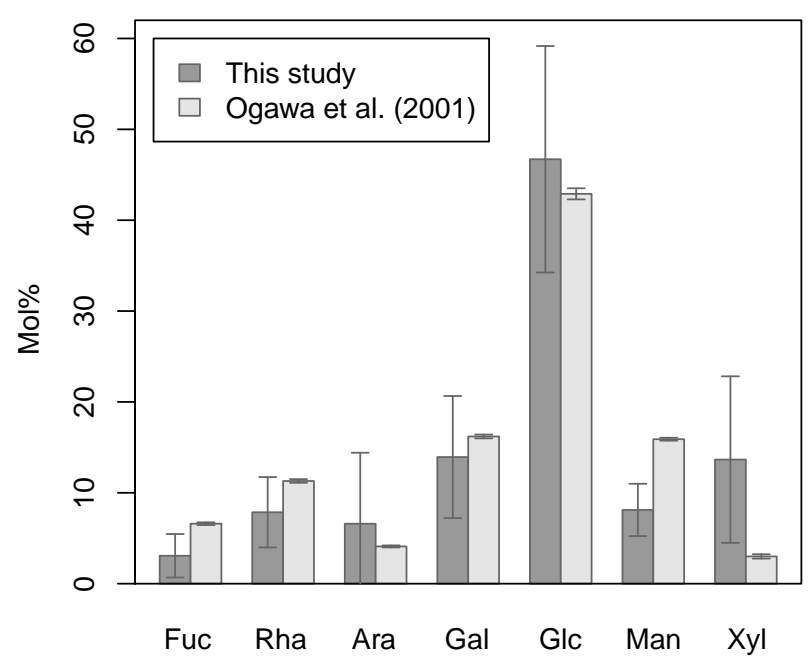

Figure 5. Molecular composition of neutral sugars produced by bacteria. Mean and standard deviations were calculated from the four glucose-enriched samples $(n=4)$. The mean and standard deviations of data from the study by Ogawa et al. (2001) were calculated from duplicate measurements of bacterially produced neutral sugars sampled on days 4 and $7(n=4)$.

labile DOC associated with the inorganic salts used to prepare the $\mathrm{ASW}_{\text {glu }}$ samples, or an inhibition of degradation of natural DOM in the presence of a simple labile substrate (Gontikaki et al., 2013). However, further studies are warranted to resolve the importance of the latter process. The significant drop in neutral sugar yields clearly reflects the labile nature of added free glucose. The amino acid yields increased at the beginning of the incubations and decreased from day 6 to day 32 - a trend also observed in previous studies (Kawasaki and Benner, 2006; Ogawa et al., 2001). The initial increase in amino acid yields is due to the significant increase in bacterial abundance and the subsequent release of amino acids.

\subsection{Bacterial production of neutral sugars during the first 6 days}

Bacterial production and the subsequent release of neutral sugars was calculated from the glucose-enriched treatments as described in the "Methods" section. The amount of neutral sugars produced during the first 6 days of the incubations (104-208 nM) was within the range of concentrations of neutral sugars observed in the ocean $(20-800 \mathrm{nM}$; Benner, 2002). The molecular composition was characterized by a high glucose mol \% (47 \pm 12$)$ and a relatively low mol \% of the remaining neutral sugars (3-14 $\pm 2-9)$, and is strikingly similar to the composition of bacterial DOM found in a study by Ogawa et al. (2001) after 7 days of incubation (Fig. 5). Calculations of the neutral sugars produced in the $\mathrm{NSW}_{\text {glu }}$ samples on day 6 are associated with uncertainty, since bacterial degradation of the natural DOM is unknown. However,

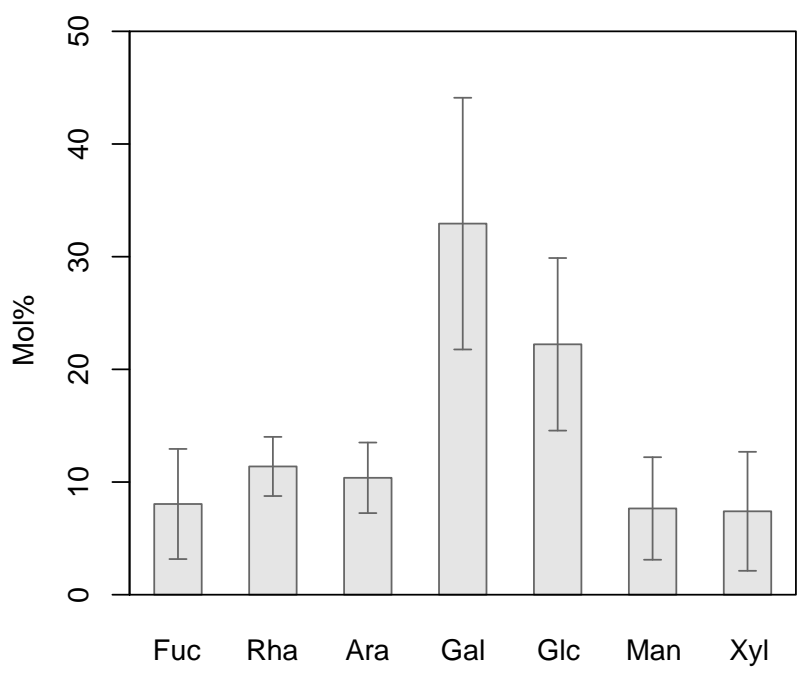

Figure 6. Molecular composition of neutral sugars on day 32 of the incubations. Means and standard deviations were calculated from all samples on day $32(n=6)$.

if only the $\mathrm{ASW}_{\text {glu }}$ samples are used when calculating the bacterially derived neutral sugars on day 6 , the results are almost identical: a high glucose mol \% of 50 and low mol \% of the remaining neutral sugars, ranging from 4 to 11 .

Similar patterns have also been observed in algal-derived DOM (Hama and Yanagi, 2001; Lazareva and Romankevich, 2012), e.g., in DOM from a fresh diatom culture (Biersmith and Benner, 1998) and from sea ice algae (Amon and Benner, 2003). However, DOM released by other algal cultures exhibit different molecular compositions of neutral sugars with galactose or xylose being most abundant (Biersmith and Benner, 1998). In the ocean, glucose is generally the most abundant neutral sugar; however, values above $30 \mathrm{~mol} \%$ are only observed occasionally (Table 3). Amon and Benner (2003) suggested that degradation processes rather than production processes determine the neutral sugar composition in the ocean, based on the similarities observed in samples of different origin (terrestrial and marine) and from different locations (oceanic regions and water masses). This can possibly explain the difference in the molecular composition of DOM in the ocean and the bacterially produced DOM after 6 days in the present study. Only small differences in neutral sugar composition between the Atlantic and Arctic samples were observed after 6 days of incubation, despite the different bacterial inocula. Moreover, there was a striking similarity in the bacteria-derived neutral sugar composition observed in the present study and in the study by Ogawa et al. (2001). Together, these results suggest that bacterially produced neutral sugars, independent of bacterial community structure, are important in shaping the molecular composition of neutral sugars in seawater. 
Table 3. Molecular composition (mol \%) of neutral sugars found in the oceans' surface, mesopelagic and deep layers. HMW DOM: $1 \mathrm{~nm}$ to $0.2 \mu \mathrm{m}$; GF/F DOM: $\sim 0.7 \mu \mathrm{m}$.

\begin{tabular}{|c|c|c|c|c|c|c|c|c|c|c|}
\hline Location & Depth (m) & DOM size & Fuc & Rha & Ara & Gal & Glc & Man & Xyl & Reference \\
\hline \multicolumn{11}{|c|}{ Surface ocean, 0-200m } \\
\hline North Pacific & 10 & HMW DOM & 16 & 12 & 9 & 19 & 17 & 13 & 12 & McCarthy et al. (1996) \\
\hline Sargasso Sea & 2 & HMW DOM & 15 & 13 & 9 & 20 & 15 & 13 & 13 & McCarthy et al. (1996) \\
\hline Gulf of Mexico & 10 & HMW DOM & 17 & 14 & 10 & 19 & 13 & 14 & 10 & McCarthy et al. (1996) \\
\hline North Pacific & $10-40$ & $0.2 \mu \mathrm{m}$ & 13 & 8 & 4 & 22 & 36 & 9 & 9 & Borch and Kirchman (1997) ${ }^{\mathrm{a}}$ \\
\hline Equatorial Pacific & $2-200$ & HMW DOM & 16 & 14 & 8 & 18 & 20 & 12 & 13 & Skoog and Benner (1997) \\
\hline Greenland Sea & $20-50$ & $\mathrm{GF} / \mathrm{F}$ & 1 & 13 & 7 & 13 & 52 & 13 & 1 & Engbrodt and Kattner (2005) \\
\hline North Pacific & $3-5$ & HMW DOM & 17 & 11 & 7 & 23 & 17 & 14 & 10 & Repeta and Aluwihare (2006) \\
\hline Sargasso Sea & $0-140$ & $\mathrm{GF} / \mathrm{F}$ & 13 & 10 & 7 & 22 & 21 & 13 & 13 & Goldberg et al. (2009) ${ }^{\mathrm{a}}$ \\
\hline Sargasso Sea & $5-200$ & Unfiltered & 14 & 12 & 11 & 21 & 17 & 12 & 13 & Kaiser and Benner (2009) \\
\hline North Pacific & $20-200$ & Unfiltered & 15 & 11 & 12 & 20 & 19 & 11 & 11 & Kaiser and Benner (2009) \\
\hline \multicolumn{11}{|c|}{ Mesopelagic ocean, $200-1000 \mathrm{~m}$} \\
\hline North Pacific & 765 & HMW DOM & 18 & 14 & 9 & 10 & 29 & 8 & 11 & McCarthy et al. (1996) \\
\hline Sargasso Sea & 900 & HMW DOM & 18 & 19 & 7 & 14 & 21 & 11 & 8 & McCarthy et al. (1996) \\
\hline Gulf of Mexico & 750 & HMW DOM & 19 & 13 & 11 & 14 & 20 & 11 & 9 & McCarthy et al. (1996) \\
\hline North Pacific & 250 & $0.2 \mu \mathrm{m}$ & 16 & 0 & 0 & 42 & 31 & 6 & 6 & Borch and Kirchman (1997) \\
\hline Equatorial Pacific & 400 & HMW DOM & 17 & 15 & 7 & 19 & 22 & 12 & 10 & Skoog and Benner (1997) \\
\hline Sargasso Sea & 250 & $\mathrm{GF} / \mathrm{F}$ & 12 & 9 & 6 & 17 & 35 & 11 & 11 & Goldberg et al. (2009) ${ }^{\mathrm{a}}$ \\
\hline Sargasso Sea & $350-900$ & Unfiltered & 17 & 11 & 12 & 19 & 18 & 11 & 12 & Kaiser and Benner (2009) \\
\hline North Pacific & $250-750$ & Unfiltered & 17 & 11 & 10 & 19 & 23 & 10 & 10 & Kaiser and Benner (2009) \\
\hline \multicolumn{11}{|c|}{ Deep ocean, 1000-5200m } \\
\hline North Pacific & 4000 & HMW DOM & 16 & 9 & 7 & 10 & 26 & 13 & 5 & McCarthy et al. (1996) \\
\hline Sargasso Sea & 2400 & HMW DOM & 19 & 17 & 10 & 13 & 17 & 10 & 11 & McCarthy et al. (1996) \\
\hline Equatorial Pacific & 4000 & HMW DOM & 16 & 14 & 3 & 19 & 19 & 13 & 12 & Skoog and Benner (1997) \\
\hline Greenland Sea & $1800-4500$ & $\mathrm{GF} / \mathrm{F}$ & 19 & 16 & 22 & 11 & 21 & 6 & 6 & Engbrodt and Kattner (2005) \\
\hline North Pacific & 5200 & HMW DOM & 25 & 15 & 8 & 19 & 12 & 12 & 9 & Repeta and Aluwihare (2006) \\
\hline Sargasso Sea & $1360-4300$ & Unfiltered & 16 & 9 & 11 & 19 & 26 & 10 & 9 & Kaiser and Benner (2009) \\
\hline North Pacific & $2000-4000$ & Unfiltered & 19 & 8 & 7 & 21 & 41 & 0 & 6 & Kaiser and Benner (2009) \\
\hline
\end{tabular}

${ }^{a}$ Mannose and xylose were stated as one value, and for simplicity, this value has been split up into two identical mol \%.

\subsection{Bacterial degradation of neutral sugars}

After 32 days, a clear degradation signature had emerged, with glucose being less important and galactose being more important (Fig. 6). This trend has also been seen in studies of marine sediments (Oakes et al., 2010). The majority of the remaining DOM after 32 days was assumed to be semi-labile or refractory, and the striking similarity between treatments indicates that the molecular composition of semi-labile or refractory neutral sugars (i.e., material persisting longer that 32 days) attains a fairly specific molecular composition, irrespective of initial DOM composition. Furthermore, the similarity between treatments suggests that bacterial degradation processes shape the composition of semi-labile or refractory neutral sugars. After 32 days, about 85 to $87 \%$ of the neutral sugars present in the $\mathrm{ASW}_{\text {glu }}$ samples are of bacterial origin (i.e., produced by bacteria during glucose assimilation), while only 13 to $15 \%$ originate from the DOM added with the inoculum (excluding glucose), assuming that neutral sug- ars in the inoculum follow the same degradation pattern as in the NSW samples, and that no refractory neutral sugars were added with the inorganic salts while preparing the artificial seawater. Hence, the molecular composition observed in the $\mathrm{ASW}_{\text {glu }}$ treatments is primarily the result of bacterially produced and bacterially altered molecules containing neutral sugars. In the NSW samples, however, the molecular composition after 32 days primarily reflects the natural background level of refractory and semi-labile neutral sugars present in the seawater when collected. Since this background signature is approaching the molecular composition of bacterially produced neutral sugars in $\mathrm{ASW}_{\text {glu }}$ samples remaining after 32 days, we hypothesize that semi-labile and refractory neutral sugars primarily originate from bacterial processing of DOM and bacterial remains. Mesocosm studies have shown that $91-94 \%$ of dissolved neutral sugars accumulated during an algal bloom were degraded within 15-20 days (Kragh and Søndergaard, 2009; Meon and Kirchman, 2001), and here we 
find that only $32-49 \%$ of the neutral sugars produced by bacteria in the $\mathrm{ASW}_{\text {glu }}$ samples were degraded within a period of 26 days, from day 6 to day 32. Neutral sugar containing molecules produced by bacteria appear to be less bioavailable than those produced by algae.

The molecular composition of neutral sugars in the deep ocean is significantly different from that observed at the end of our incubation experiments, although both reflect a high degree of bacterial degradation and transformation. Our results indicate that bacterially degraded neutral sugars have a high galactose mol \% (Table 1, Fig. 6), but measurements in the deep ocean reveal a high glucose mol \% (Table 3). This discrepancy has been seen in other studies as well (e.g., Amon et al., 2001), and can be due to fundamental environmental differences between the ocean interior and bioassay incubations and the different timescales of carbon cycling. However, the difference can possibly also be due to differences in diagenetic state of the neutral sugars in the deep ocean and in the surface waters sampled for this study. In addition, it is possible that bacterial degradation of particulate organic material (POM) plays a major role in shaping the molecular composition in the deep ocean. POM supports a major fraction of the respiratory carbon demand below the photic layer (Arístegui et al., 2002) and POM is known to have a high glucose content (Hernes et al., 1996; Panagiotopoulos and Sempéré, 2007). In our incubations, only the $10 \%$ inoculum contained POM, and it is likely that our results mainly reflect bacterial degradation of DOM, either DOM produced by bacteria from glucose or DOM initially present in the samples, while deep ocean observations mainly reflect bacterial degradation of POM. Finally, the high glucose mol \% in the deep ocean possibly reflects bacterially produced neutral sugars with a high glucose content (Fig. 5), or other neutral sugar sources also having a high glucose mol \%, e.g., submarine vent microbes (Skoog et al., 2007). In the Pacific Ocean, the glucose mol \% is significantly higher than in the Atlantic Ocean (Kaiser and Benner, 2009), supporting the hypothesis that the bacterially produced neutral sugars become more important with time in the deep ocean. However, further studies are needed to fully understand bacterial degradation of neutral sugars bound in DOM and POM and the connection between in situ measurements and incubation studies.

\subsection{Bacterial degradation of amino acids}

The molecular composition of amino acids did not vary considerably between samples, nor did it change over the time course of the experiments (Table 2). The most abundant amino acid was glycine with a mol \% between 26 and 40 followed by aspartic acid, glutamic acid, serine and alanine, which all typically ranged from 10 to $15 \mathrm{~mol} \%$. The same trends are seen in the ocean, except that the mol \% of glycine is somewhat lower (15-32) and the mol \% of $\gamma$-aminobutyric acid increases with depth (Table 4). A high glycine content

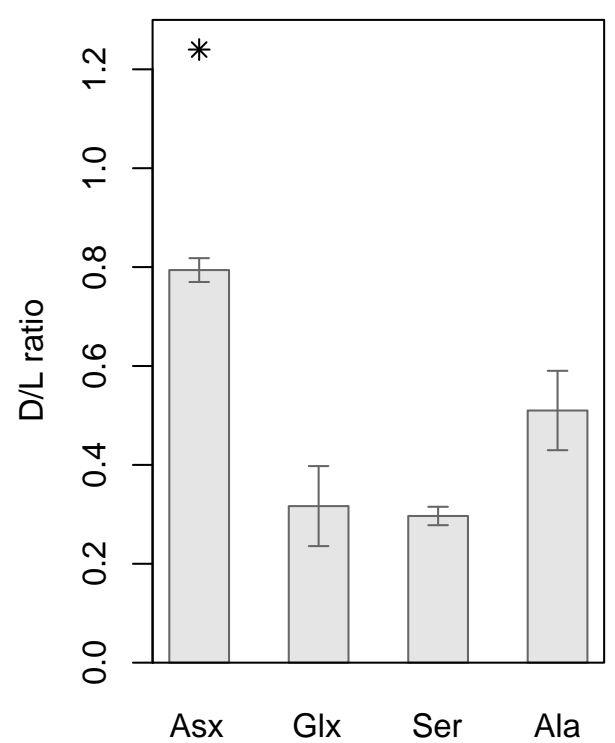

Figure 7. Mean amino acid D/L ratios on day 32 of the incubations. Means and standard deviations were calculated from all samples on day $32(n=6)$. Asx did not include the artificial Arctic sample, which had a considerably higher $\mathrm{D} / \mathrm{L}$ ratio than the rest of the samples (indicated with a star).

is generally associated with highly degraded organic matter (Dauwe et al., 1999), however, the high mol \% observed in our incubations are rarely seen in the ocean (Table 4). The $\gamma$-aminobutyric amino acid is known to increase with depth in the ocean, and has therefore been used as an indicator of organic matter diagenesis (Dauwe and Middelburg, 1998; Davis et al., 2009). No consistent increase in $\gamma$-aminobutyric acid is seen during our incubations, suggesting that the increase observed in the ocean could result from long-term degradation. This hypothesis is consistent with results from a study by Davis et al. (2009), who found an increase in $\gamma$ aminobutyric acid of only $0-7 \mathrm{~mol} \%$ during 20-33 days of incubation experiments.

The four measured amino acids with $\mathrm{L}-$ and $\mathrm{D}-$ enantiomers exhibited a clear degradation pattern (Fig. 7). Despite very different $\mathrm{D} / \mathrm{L}$ ratios at the beginning of the experiment, all treatments ended up having almost identical ratios after only 32 days (Table 2 ). The $\mathrm{D} / \mathrm{L}$ ratios of amino acids in NSW samples generally remained constant or increased slightly during the incubations. In the glucoseenriched samples, however, the ratio increased significantly, and after 32 days, all treatments had almost similar $\mathrm{D} / \mathrm{L}$ ratios. This trend was especially clear for aspartic acid (except for the Arctic ASW glu sample indicated in the figure) and serine, where the variability after 32 days was minimal. As exceptions, the Atlantic and Arctic samples seemed to have slightly different $\mathrm{D} / \mathrm{L}$ ratios of glutamic acid after 32 days, with Atlantic samples being below 0.27 and Arctic samples above 0.35 . Hence, the amount of D-amino acids produced relative to L-amino acids utilized was higher in 
Table 4. Molecular composition (mol \%) of amino acids found on the ocean surface and in mesopelagic and deep layers. HMW DOM: $1 \mathrm{~nm}$ to $0.2 \mu \mathrm{m}$; GF/F DOM: $\sim 0.7 \mu \mathrm{m}$. nd: no data.

\begin{tabular}{|c|c|c|c|c|c|c|c|c|c|c|c|c|}
\hline Location & Depth (m) & DOM size & Asx & Glx & Ser & Gly & Arg & Ala & Leu & $\beta-$ ala & $\gamma-\mathrm{aba}$ & Reference \\
\hline \multicolumn{13}{|c|}{ Surface ocean, $0-200 \mathrm{~m}$} \\
\hline North Pacific & $20-200 \mathrm{~m}$ & Unfiltered & 10 & 14 & 8 & 26 & 2 & 15 & 2 & 5 & 2 & Kaiser and Benner (2009) \\
\hline North Pacific & $10 \mathrm{~m}$ & HMW DOM & 11 & 18 & 10 & 16 & 4 & 13 & 5 & 1 & 0 & McCarthy et al. (1996) \\
\hline North Pacific & $0-400 \mathrm{~m}$ & $\mathrm{GF} / \mathrm{F}$ & 10 & 11 & 12 & 19 & 9 & 15 & 4 & nd & nd & Yamashita and Tanoue (2003) \\
\hline Chukchi Sea & $0-200 \mathrm{~m}$ & $\mathrm{GF} / \mathrm{F}$ & 12 & 8 & 5 & 29 & 2 & 13 & 1 & 8 & 8 & Davis and Benner (2005) \\
\hline Sargasso Sea & $20-100 \mathrm{~m}$ & Unfiltered & 8 & 9 & 6 & 23 & 6 & 14 & 2 & 5 & 7 & Kaiser and Benner (2009) \\
\hline Sargasso Sea & $2 \mathrm{~m}$ & HMW DOM & 10 & 15 & 9 & 15 & 6 & 16 & 5 & 1 & 2 & McCarthy et al. (1996) \\
\hline Gulf of Mexico & $10 \mathrm{~m}$ & HMW DOM & 12 & 16 & 11 & 17 & 3 & 16 & 3 & 2 & 0 & McCarthy et al. (1996) \\
\hline \multicolumn{13}{|c|}{ Mesopelagic ocean, $200-1000 \mathrm{~m}$} \\
\hline North Pacific & $250-750 \mathrm{~m}$ & Unfiltered & 11 & 12 & 7 & 28 & 3 & 17 & 0 & 6 & 4 & Kaiser and Benner (2009) \\
\hline North Pacific & 765 & HMW DOM & 9 & 12 & 6 & 21 & 2 & 15 & 5 & 4 & 0 & McCarthy et al. (1996) \\
\hline Chukchi Sea & $201-1000 \mathrm{~m}$ & Unfiltered & 12 & 6 & 4 & 32 & 1 & 13 & 1 & 7 & 14 & Davis and Benner $(2005)^{\mathrm{b}}$ \\
\hline Sargasso Sea & $350-500 \mathrm{~m}$ & Unfiltered & 8 & 18 & 5 & 16 & 4 & 15 & 3 & 3 & 8 & Kaiser and Benner (2009) \\
\hline Sargasso Sea & 900 & HMW DOM & 10 & 18 & 7 & 16 & 8 & 14 & 5 & 1 & 0 & McCarthy et al. (1996) \\
\hline Gulf of Mexico & 750 & HMW DOM & 11 & 18 & 7 & 16 & 7 & 12 & 5 & 1 & 0 & McCarthy et al. (1996) \\
\hline \multicolumn{13}{|c|}{ Deep ocean, $1000-4300 m$} \\
\hline North Pacific & $2000-4000 \mathrm{~m}$ & Unfiltered & 11 & 10 & 3 & 27 & 3 & 20 & 0 & 6 & 9 & Kaiser and Benner (2009) \\
\hline North Pacific & $4000 \mathrm{~m}$ & HMW DOM & 10 & 15 & 12 & 18 & 5 & 10 & 1 & 2 & 1 & McCarthy et al. (1996) \\
\hline Chukchi Sea & $1000 \mathrm{~m}$ & Unfiltered & 11 & 5 & 5 & 30 & 2 & 13 & 1 & 6 & 19 & Davis and Benner (2005) \\
\hline Sargasso Sea & $1360-4300 \mathrm{~m}$ & Unfiltered & 11 & 9 & 6 & 22 & 6 & 10 & 2 & 5 & 13 & Kaiser and Benner (2009) \\
\hline Sargasso Sea & $2400 \mathrm{~m}$ & HMW DOM & 13 & 17 & 8 & 20 & 5 & 18 & 3 & 1 & nd & McCarthy et al. (1996) \\
\hline
\end{tabular}

a Most sampling sites were shallower than $200 \mathrm{~m}$.

b Samples collected above $300 \mathrm{~m}$ were GF/F filtered and samples collected below $300 \mathrm{~m}$ were unfiltered.

Arctic samples than in Atlantic samples. Previous studies have also reported increased $\mathrm{D} / \mathrm{L}$ ratios with time in degradation experiments (Amon et al., 2001; Jørgensen et al., 1999) and with depth in the ocean (Dittmar et al., 2001; Kaiser and Benner, 2008). The common endpoints in the $\mathrm{D} / \mathrm{L}$ ratios observed here have not previously been observed, and suggest that a degradation signature exists. It appears that DOM sources (Arctic DOM, Atlantic DOM and glucose) and the bacterial community (Arctic versus Atlantic) have a minor influence on $\mathrm{D} / \mathrm{L}$ amino acid ratios, except for glutamic acid, where the bacterial community structure to some extent might influence the ratio. The fact that $\mathrm{D} / \mathrm{L}$ ratios in the NSW samples equal bacterially produced $\mathrm{D} / \mathrm{L}$ ratios in $\mathrm{ASW}_{\text {glu }}$ samples after 32 days indicates that bacteria are the dominant source of amino acids in semi-labile and refractory DOM.

The $\mathrm{D} / \mathrm{L}$ ratios observed at the end of the incubation experiments were considerably higher than $\mathrm{D} / \mathrm{L}$ ratios in the deep ocean (Kaiser and Benner, 2008; McCarthy et al., 1998; Pérez et al., 2003). In our experiments as well as in the ocean, the highest $\mathrm{D} / \mathrm{L}$ ratio is that of aspartic acid, followed by the $\mathrm{D} / \mathrm{L}$ ratio of alanine and the (almost equal) $\mathrm{D} / \mathrm{L}$ ratios of glutamic acid and serine. However, the $\mathrm{D} / \mathrm{L}$ ratios observed after 32 days in our incubations were about 0.1 to 0.3 units higher than in the deep ocean (Fig. 7, McCarthy et al. 1998). The timescale of the incubation experiments was much shorter than the timescale of the ocean circulation, and it is possi- ble that deep ocean amino acids exhibit a different $\mathrm{D} / \mathrm{L}$ ratio due to a higher degree of diagenesis. The observed difference could also reflect the fact that the incubations included a larger fraction of DOM of bacterial origin and therefore had a higher D-amino acid content than DOM and POM in the ocean. The main sources of D-amino acids are bacterial cell wall membrane components, including peptidoglycans, lipopolysaccharides and lipopeptides (Kaiser and Benner, 2008). The $\mathrm{ASW}_{\text {glu }}$ samples demonstrated that during bacterial utilization of glucose and subsequent degradation of bacterial remnants, DOM with high $\mathrm{D} / \mathrm{L}$ amino acid ratios is produced. The DOM and POM available for bacterial degradation in the ocean, however, is probably derived from many different sources (Kaiser and Benner, 2008).

\subsection{Implications}

Bacteria play an important role in shaping the concentration and composition of neutral sugars and amino acids in the ocean. Our results show that bacteria are capable of changing the composition of biomolecules bound in DOM significantly within short timescales, and that biomolecule yields can be used as indicators of DOC bioavailability. Bacterial transformation of labile DOM to refractory DOM via the microbial carbon pump has been suggested as an important production pathway of refractory DOM (Jiao et al., 2010; Ogawa et al., 2001). Results from the present incubations indicate that the microbial carbon pump also applies 
for neutral sugars and amino acids: the molecular composition of biomolecules produced by bacteria and biomolecules remaining after degradation of bacterial remnants in $\mathrm{ASW}_{\text {glu }}$ samples was strikingly similar to the composition of semilabile or refractory biomolecules remaining in NSW samples after 32 days, suggesting that bacterially produced biomolecules can persist for long periods in the ocean. The present study provides preliminary indications of microbial production of refractory biomolecules via the microbial carbon pump, but further studies are needed to test this hypothesis and better understand its quantitative importance.

Acknowledgements. The authors thank the captain, crew and scientists onboard R/V Dana, Helle Knudsen-Leerbeck and Susan Rasmussen for help with planning and setting up the experiment, and Mike Philben for assistance with the neutral sugar analyses. This work was supported by the Danish Strategic Research Council for the NAACOS project (grant no. 10-093903), the Danish Center for Marine Research (grant no. 2012-01), the Danish Research Council for Independent Research (FNU-09-072829), and the US National Science Foundation (grant no. 1233373). The authors also thank two anonymous reviewers for comments that helped improve the manuscript.

Edited by: G. Herndl

\section{References}

Amon, R. M. W. and Benner, R.: Combined neutral sugars as indicators of the diagenetic state of dissolved organic matter in the Arctic Ocean, Deep Sea Res. Pt. I, 50, 151-169, doi:10.1016/S09670637(02)00130-9, 2003

Amon, R. M. W., Budéus, G. and Meon, B.: Dissolved organic carbon distribution and origin in the Nordic Seas: Exchanges with the Arctic Ocean and the North Atlantic, J. Geophys. Res., 108, 1-17, doi:10.1029/2002JC001594, 2003.

Amon, R. M. W., Fitznar, H.-P., and Benner, R.: Linkages among the bioreactivity, chemical composition, and diagenetic state of marine dissolved organic matter, Limnol. Oceanogr., 46, 287297, 2001

Arístegui, J., Duarte, C. M., Agustí, S., Doval, M., AlvarezSalgado, X. A., and Hansell, D. A.: Dissolved organic carbon support of respiration in the dark ocean, Science, 298, 1967, doi:10.1126/science.1076746, 2002.

Benner, R.: Chemical composition and reactivity, in Biogeochemistry of marine dissolved organic matter, edited by: Hansell, D. A. and Carlson, C. A., 59-90, Academic Press., 2002.

Benner, R. and Herndl, G. J.: Bacterially derived dissolved organic matter in the microbial carbon pump, in Microbial carbon pump in the ocean, edited by: Jiao, N., Azam, F., and Sanders, S., 4648, Science/AAAS., 2011.

Benner, R., Louchouarn, P., and Amon, R. M. W.: Terrigenous dissolved organic matter in the Arctic Ocean and its transport to surface and deep waters of the North Atlantic, Global Biogeochem. Cycles, 19, GB2025, doi:10.1029/2004GB002398, 2005.
Benner, R., Pakulski, J. D., McCarthy, M., Hedges, J. I., and Hatcher, P. G.: Bulk chemical characteristics of dissolved organic matter in the ocean, Science, 255, 1561-1564, 1992.

Biersmith, A. and Benner, R.: Carbohydrates in phytoplankton and freshly produced dissolved organic matter, Mar. Chem., 63, 131144, doi:10.1016/S0304-4203(98)00057-7, 1998.

Borch, N. H. and Kirchman, D. L.: Concentration and composition of dissolved combined neutral sugars (polysaccharides) in seawater determined by HPLC-PAD, Mar. Chem., 57, 85-95, doi:10.1016/S0304-4203(97)00002-9, 1997.

Dauwe, B. and Middelburg, J. J.: Amino acids and hexosamines as indicators of organic matter degradation state in North Sea sediments, Limnol. Oceanogr., 43, 782-798, doi:10.4319/lo.1998.43.5.0782, 1998.

Dauwe, B., Middelburg, J. J., Herman, P. M. J., and Heip, C. H. R.: Linking diagenetic alteration of amino acids and bulk organic matter reactivity, Limnol. Oceanogr., 44, 1809-1814, 1999.

Davis, J. and Benner, R.: Seasonal trends in the abundance, composition and bioavailability of particulate and dissolved organic matter in the Chukchi/Beaufort Seas and western Canada Basin, Deep Sea Res. Pt II, 52, 3396-3410, doi:10.1016/j.dsr2.2005.09.006, 2005.

Davis, J., Kaiser, K., and Benner, R.: Amino acid and amino sugar yields and compositions as indicators of dissolved organic matter diagenesis, Org. Geochem., 40, 343-352, doi:10.1016/j.orggeochem.2008.12.003, 2009.

Dittmar, T., Fitznar, H. P. and Kattner, G.: Origin and biogeochemical cycling of organic nitrogen in the eastern Arctic Ocean as evident from D- and L-amino acids, Geochim. Cosmochim. Acta, 65(22), 4103-4114, 2001.

Engbrodt, R. and Kattner, G.: On the biogeochemistry of dissolved carbohydrates in the Greenland Sea (Arctic), Org. Geochem., 36, 937-948, doi:10.1016/j.orggeochem.2004.12.007, 2005.

Goldberg, S. J., Carlson, C. A., Hansell, D. A., Nelson, N. B., and Siegel, D. A.: Temporal dynamics of dissolved combined neutral sugars and the quality of dissolved organic matter in the Northwestern Sargasso Sea, Deep Sea Res. Pt. I, 56, 672-685, doi:10.1016/j.dsr.2008.12.013, 2009.

Gontikaki, E., Thornton, B., Huvenne, V. A. I., and Witte, U.: Negative priming effect on organic matter mineralisation in NE Atlantic slope sediments, PLoS One, 8, e67722, doi:10.1371/journal.pone.0067722, 2013.

Hama, T. and Yanagi, K.: Production and neutral aldose composition of dissolved carbohydrates excreted by natural marine phytoplankton populations, Limnol. Oceanogr., 46, 1945-1955, doi:10.4319/lo.2001.46.8.1945, 2001.

Hansell, D. A.: Recalcitrant dissolved organic carbon fractions, Ann. Rev. Mar. Sci., 5, 421-45, doi:10.1146/annurev-marine120710-100757, 2013.

Hernes, P. J., Hedges, J. I., Peterson, M. L., Wakeham, S. G. and Lee, C.: Neutral carbohydrate geochemistry of particulate material in the central equatorial Pacific, Deep Sea Res. Pt. II, 43, 1181-1204, doi:10.1016/0967-0645(96)00012-4, 1996.

Hopkins, D. W., Isabella, B. L., and Scott, S. E.: Relationship between microbial biomass and substrate induced respiration in soils amended with D- and L-isomers of amino acids, Soil Biol. Biochem., 26, 1623-1627, doi:10.1016/0038-0717(94)90314-X, 1994. 
Jiao, N., Herndl, G. J., Hansell, D. A., Benner, R., Kattner, G., Wilhelm, S. W., Kirchman, D. L., Weinbauer, M. G., Luo, T., Chen, F., and Azam, F.: Microbial production of recalcitrant dissolved organic matter: long-term carbon storage in the global ocean, Nat. Rev. Microbiol., 8, 593-599, doi:10.1038/nrmicro2386, 2010.

Jørgensen, N. O. G., Tranvik, L. J., and Berg, G. M.: Occurrence and bacterial cycling of dissolved nitrogen in the Gulf of Riga, the Baltic Sea, Mar. Ecol. Prog. Ser., 191, 1-18, 1999.

Kaiser, K. and Benner, R.: Hydrolysis-induced racemization of amino acids, Limnol. Oceanogr. Methods, 3, 318-325, 2005.

Kaiser, K. and Benner, R.: Major bacterial contribution to the ocean reservoir of detrital organic carbon and nitrogen, Limnol. Oceanogr., 53, 99-112, doi:10.4319/lo.2008.53.1.0099, 2008.

Kaiser, K. and Benner, R.: Biochemical composition and size distribution of organic matter at the Pacific and Atlantic time-series stations, Mar. Chem., 113, 63-77, doi:10.1016/j.marchem.2008.12.004, 2009.

Kawasaki, N. and Benner, R.: Bacterial release of dissolved organic matter during cell growth and decline: Molecular origin and composition, Limnol. Oceanogr., 51, 2170-2180, doi:10.4319/lo.2006.51.5.2170, 2006.

Kester, D. R., Duedall, I. W., Connors, D. N., and Pytkowicz, R. M.: Preparation of artificial seawater, Limnol. Oceanogr., 12, 176179, available at: www.jstor.org/stable/10.2307/2833179, 1967.

Kirchman, D. L., Meon, B., Ducklow, H. W., Carlson, C. A., Hansell, D. A., and Steward, G. F.: Glucose fluxes and concentrations of dissolved combined neutral sugars (polysaccharides) in the Ross Sea and Polar Front Zone, Antarctica, Deep Sea Res. Pt. II, 48, 4179-4197, doi:10.1016/S0967-0645(01)000856, 2001.

Kragh, T. and Søndergaard, M.: Production and decomposition of new DOC by marine plankton communities: carbohydrates, refractory components and nutrient limitation, Biogeochemistry, 96, 177-187, doi:10.1007/s10533-009-9357-1, 2009.

Lazareva, E. V and Romankevich, E. A.: Carbohydrates as indicators of biogeochemical processes, Oceanology, 52, 335-344, doi:10.1134/S0001437012020075, 2012.

Lee, C. and Bada, J. L.: Dissolved amino acids in the equatorial Pacific, the Sargasso Sea, and Biscayne Bay, Limnol. Oceanogr., 22, 502-510, 1977.

Marie, D., Partensky, F., Jacquet, S., and Vaulot, D.: Enumeration and cell cycle analysis of natural populations of marine picoplankton by flow cytometry using the nucleic acid stain SYBR Green I, Appl. Environ. Microbiol., 63, 186-193, 1997.

McCarthy, M. D., Hedges, J. I. and Benner, R.: Major bacterial contribution to marine dissolved organic nitrogen, Science, 281, 231-234, doi:10.1126/science.281.5374.231, 1998.

McCarthy, M., Hedges, J. I., and Benner, R.: Major biochemical composition of dissolved high molecular weight organic matter in seawater, Mar. Chem., 55, 281-297, doi:10.1016/S03044203(96)00041-2, 1996.

Meon, B. and Kirchman, D. L.: Dynamics and molecular composition of dissolved organic material during experimental phytoplankton blooms, Mar. Chem., 75(3), 185-199, doi:10.1016/S0304-4203(01)00036-6, 2001.

Middelboe, M. and Jørgensen, N. O. G.: Viral lysis of bacteria: an important source of dissolved amino acids and cell wall compounds, J. Mar. Biol. Assoc. UK, 86, 605-612, doi:10.1017/S0025315406013518, 2006.

Oakes, J. M., Eyre, B. D., Middelburg, J. J., and Boschker, H. T. S.: Composition, production, and loss of carbohydrates in subtropical shallow subtidal sandy sediments: Rapid processing and long-term retention revealed by 13C-labeling, Limnol. Oceanogr., 55, 2126-2138, doi:10.4319/lo.2010.55.5.2126, 2010.

Ogawa, H., Amagai, Y., Koike, I., Kaiser, K., and Benner, R.: Production of refractory dissolved organic matter by bacteria, Science, 292, 917-20, doi:10.1126/science.1057627, 2001.

Opsahl, S., Benner, R., and Amon, R. M. W.: Major flux og terrigenous dissolved organic matter through the Arctic Ocean, Limnol. Oceanogr., 44, 2017-2023, 1999.

Panagiotopoulos, C. and Sempéré, R.: Sugar dynamics in large particles during in vitro incubation experiments, Mar. Ecol. Prog. Ser., 330, 67-74, doi:10.3354/meps330067, 2007.

Pérez, M. T., Pausz, C., and Herndl, G. J.: Major shift in bacterioplankton utilization of enantiomeric amino acids between surface waters and the ocean's interior, Limnol. Oceanogr., 48, 755-763, 2003.

Raymond, P. A., McClelland, J. W., Holmes, R. M., Zhulidov, A. V., Mull, K., Peterson, B. J., Striegl, R. G., Aiken, G. R., and Gurtovaya, T. Y.: Flux and age of dissolved organic carbon exported to the Arctic Ocean: A carbon isotopic study of the five largest arctic rivers, Global Biogeochem. Cycles, 21, GB4011, doi:10.1029/2007GB002934, 2007.

Repeta, D. J. and Aluwihare, L. I.: Radiocarbon analysis of neutral sugars in high-molecular-weight dissolved organic carbon: Implications for organic carbon cycling, Limnol. Oceanogr., 51, 1045-1053, 2006.

Rich, J., Gosselin, M., Sherr, E., Sherr, B. and Kirchman, D. L.: High bacterial production, uptake and concentrations of dissolved organic matter in the Central Arctic Ocean, Deep Sea Res. Pt. II, 44, 1645-1663, available at: http://www.sciencedirect. com/science/article/pii/S0967064597000581, 1997.

Rich, J. H., Ducklow, H. W., and Kirchman, D. L.: Concentrations and uptake of neutral monosaccharides along $140^{\circ} \mathrm{W}$ in the equatorial Pacific: Contribution of glucose to heterotrophic bacterial activity and the DOM flux, Limnol. Oceanogr., 41, 595604, doi:10.4319/lo.1996.41.4.0595, 1996.

Shen, Y., Fichot, C. G., and Benner, R.: Dissolved organic matter composition and bioavailability reflect ecosystem productivity in the Western Arctic Ocean, Biogeosciences, 9, 4993-5005, doi:10.5194/bg-9-4993-2012, 2012.

Siegenthaler, U. and Sarimento, J. L.: Atmospheric carbon dioxide and the ocean, Nature, 365, 119-125, available at: http://www. gfdl.noaa.gov/bibliography/related_files/us9301.pdf, 1993.

Skoog, A. and Benner, R.: Aldoses in various size fractions of marine organic matter: implications for carbon cycling, Limnol. Oceanogr., 42, 1803-1813, 1997.

Skoog, A., Biddanda, B., and Benner, R.: Bacterial utilization of dissolved glucose in the upper water column of the Gulf of Mexico, Limnol. Oceanogr., 44, 1625-1633, doi:10.4319/lo.1999.44.7.1625, 1999.

Skoog, A., Vlahos, P., Rogers, K. L., and Amend, J. P.: Concentrations, distributions, and energy yields of dissolved neutral aldoses in a shallow hydrothermal vent sys- 
tem of Vulcano, Italy, Org. Geochem., 38, 1416-1430, doi:10.1016/j.orggeochem.2007.03.005, 2007.

Stein, M.: Variability of water masses, currents and ice in Denmark Strait, Sci. Counc. Stud., 12, 71-84, 1988.
Yamashita, Y. and Tanoue, E.: Distribution and alteration of amino acids in bulk DOM along a transect from bay to oceanic waters, Mar. Chem., 82, 145-160, doi:10.1016/S0304-4203(03)00049-5, 2003 